\title{
日常語をベースとした順序ソート論理による知識 表現法と关の推論処理法
}

\section{A Knowledge Representation Scheme Using Ordinary Words and the Inference Mechanism on Order-sorted Logic}

\author{
石川 勉 拓殖大学工学部情報工学科 \\ Tsutomu Ishikawa Department of Computer Science, Faculty of Engineering, Takushoku University \\ ben@cs.takushoku-u.ac.jp
}

keywords: knowledge representation, inference method, order-sorted logic, natural language

\section{Summary}

We propose a knowledge representation scheme (called WPL) and an inference method for the scheme. In WPL, both simple sentence and complex sentence are represented in one atomic formula. Subordinate clauses in a complex sentence are embedded into the formula forming the main clause. WPL is an extended order-sorted logic that can deal with structured sort symbols consisting of multiple ordinary words like noun phrases. Each word in a sort symbol can represent a general concept or a particular object. If it is the latter, each word stands for a variable or constant having itself as a sort symbol. It may also be a proper noun or variable itself. The inference processes for WPL is executed based on the resolution principle, semantically interpreting the sort symbols word by word. We extend the inference rules proposed by Beierle et al. in order to deal with complex sort symbols. This paper also describes an application scheme of the proposed inference rules and an algorithm for judging the subsort relation between complex sort symbols.

\section{1.は じめに}

人間と自然に対話できるロボットの実現は我々研究者 の長年の夢である.対話システムはチケット販売等限定 的な応用では実用的になりつつあるが, 話題を限定しな い場合は，Loebner コンテスト等からも分かるように未 だに Eliza の域を脱したとは言い難い .

一方, 最近のWeb 情報の爆発的な増加, 普及に伴い， これを利用した質問応答システム，コンサルティングシ ステムへの高度な意味処理の適用が求められている.こ れに応えるべくセマンティック Web の研究も活発化し， RDF(Resource Description Framework)や XML (Extensible Markup Language) および光れらをべースとす るオントロジー言語 OWL(Web Ontology language) 等 の整備により，Web 情報からの知識利用が可能になりつ つある [Antoniou 07] .しかし，これはタグ付けされて いる情報に対してであり，既存のWeb 情報や一般の電子 化文書のすべてにタグ付けがなされるとは考えづらい .

すなわち，このような電子化情報の有効利用さらには 前述の対話システムの高度化には, 自然言語文を一定の 知識表現へ変換し光れを用いて効率的に推論する技術の 確立が要求されてくる.しかも実用上は，これらは一貫 して自動化が可能でなければならない．
知識表現法としては,フレーム, 意味ネット,ルールベー ス，述語論理が代表的であり，これまで光れらをべースと した多くの拡張形式力提案されている.最近では，Web 情 報の国際的な利用のための UNL(Universal Networking Digital Language)[UNL, 石塚 06] , オントロジー記述へ の適用性を意識した DL(Description Logic)[Brachman 84, 兼岩 03] 等も注目されている.しかし，これらは知 識利用の容易化や共通化に重きを置いており，推論との 結合を意識した場合には述語論理ベースの表現法か現実 的と言える.したがって，推論法もこれが前提となるが， 従来の単純な一階述語論理では表現能力だけでなく知識 が大規模化したときの処理時間にも問題があり，自然言 語文に適した何らかの拡張が必要となる .

このような背景から，ここでは多くの知識表現法の中か ら，(1)単一化に基づく強力な推論との結合という観点か ら述語論理ベースの表現法 , (2)効率的な推論処理の観点 から照合範囲を限定できるソート論理, (3)自然言語文に 対する推論という観点から語彙知識と規則的知識の結合 に有利な順序ソート論理, という絞込みにより順序ソート 論理 [Walther 88, Cohn 87] を選ぶ. 本論文では, 光の表 現能力をさらに拡張した知識表現法 WPL(Words-based extended Predicate Logic)および光れに対する効率的 な推論処理法を提案する .これらは最終的には知識ベー 


\section{ス上での推論を目的としている}

WPL は、現在の自然言語処理技術の活用による自動変 換を意識した日常語べースの知識表現法であり，最大の 特徵はソートに単純な概念でなく名詞句のような構造を 持った概念を許容する点にある.この構造を持ったソー 卜を用い, 単文, 複文に係わらず一つの自然言語文は一 つの述語式(素式)で,かつ見通しがよい形で表わされる 複文の場合には主節が述語式の基本を構成し，従属節は 述語部あるいは引数部 (項)に埋め込んで表現される.さ らに従属節も述語式を使って表現するため循環構造を持っ た表現形式となる．また，引数部には深層格を用い，引 数自体はソート付きの定数, 変数とし, 光のソート中に も変数の使用を許容する.

WPL に対する推論法は，このような複雑な構造を持 つソートを扱う必要があり,ここでは, Beierle らによっ て提案されている拡張型順序ソート論理 [Beierle 92] を さらに拡張する，具体的には，WPLにおいて名詞句と して一䌂りとして扱っていたソートを兴の内部構造まで 立ち入って推論処理できるように, 導出処理に SLp 節と 呼:ジ一種の処理の繰り延へ項を導入した推論規則を提案 する. 本推論法は , 構造を持ったソートの意味的な包含 関係を判定しながら導出処理を進めるもので, 広い意味 での解釈の一部が推論プロセス中に持ち込まれることに なる .

本論文では，2 章で研究の動機およびWPL の表現対 象・構成・表現法について述べる．3 章では，WPLに対 する推論法の基本的な考え方, Beierle らの推論規則およ び炎の拡張について述べる.4 章では，拡張した推論規 則の適用において重要となる，構造を持ったソート間の サブソート関係の判定法と光れに基づくSLp 節の生成法 について述べる.また，5章では本推論法の具体的な適 用例を示し， 6 章では従来の順序ソート論理に対する優 位性，推論規則の健全性と完全性等について考察する。

\section{2. 日常語ベースの知識表現法 WPL}

\section{$2 \cdot 1$ 研 究の 動 機}

本論文は 1 章で述べたように知識表現法と关の推論法 の提案であり知識への変換法の提案ではないが, これら は自然言語文を推論で扱う場合一貫性をもって捉える必 要があるため，ここではまず後者について簡単にふれる． 次に, 前者のベースとなる順序ソート論理の概要と午の 拡張の必要性について述べる．なお，本論文で提案する WPL への変換法については別途報告する予定である .

(1) 自然言語文からの変換可能性

自然言語文の論理式表現については，モンタギュー文 法 [Montague 73, 白井 85] 以降広く研究されてきた .し かし, 情報伝達を目的としかつ曖昧性を有する自然言語 と真偽を扱う論理とは本質的に相容れない面があり，極 めて難しい課題である. 従って , 現在でも実用的なレベ
ルに達しているとは言い難いが, 曖昧性の解消を目指し た研究や，ACE[Fuchs 06]のように対象とする文を曖昧 性の無い範囲に限定したアプローチ等がなされている [石 川 07] . 筆者らも，茶笔，南瓜 [松本 04] 等の解析ツール やEDR 電子化辞書 [EDR 96] 等を用いた自動変換法に ついて研究しており, 簡単な文については変換可能とし ている [佐々木 04]．最近はさらに，Web 情報をコーパ スとして利用した格解析の高精度化も進み [黑橋 07]，少 しづつではあるがこの可能性は高まっている．すなわち， 完璧性を求めなければ実用に近づきつつあると言える .

(2) ソート論理と順序ソート論理

ソート論理は, 一階述語論理における変数や定数を, ソートと呼ばれる限定されたドメインの 1 つの要素 (個 体)であるとして扱う方法である.ソート $s$ に属する個体 $t$ をソート論理では $t: s$ のように表す .これにより，推 論処理 (単一化) における照合範囲力限定され关の効率化 が図れる。

順序ソート論理では,さらに兴のソート間に上位下位 の階層関係 (ソート階層) か溥入される .これはサブソー

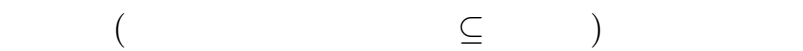
えば，「医者」と「専門家」の間には，“医者 $\subseteq$ 専門家” と いう関係がある．この場合，「医者」は「専門家」のサブ ソートであるという . ソート階層において上位下位の関 係は集合論的に扱われ，下位のソートに含まれる要素は 上位のソートに必ず含まれる . 先の例で言うならば,「医 者」であるならば誰もが「専門家」でもあるということで ある．したがって，順序ソート論理では，ソート $s_{1} \subseteq s_{2}$ なら, $\forall x\left[Q\left(x: s_{2}\right) \rightarrow Q\left(c: s_{1}\right)\right]$ の関係が成り立つ.例 えば $Q$ が「賢い」という述語だとすると，先の例では， 「すべての専門家 $x$ か賢ければ医者 $c$ は賢い」ということ になり，これは真である．なお，最上位のソートはトッ プソートと呼ばれ，ここではこれを丁と表す．

順序ソート論理は,以上の説明からも分かるように階層 性を有する語彙知識と論理式で表される規則的知識との結 合に適している.このため近年, 知識やデータを階層的に 整理し利用する必要性が高まりつつあることから再び注目 されてきており，ソート階層と論理式の密な結合 [Beierle 92]，階層構造を持った多項述語への拡張 [Kaneiwa 04]， 形式オントロジーの property 分類を導入した拡張 [兼岩 05] 等々活発に研究されてきている.

(3) 拡張の必要性

順序ソート論理は, 以上のように語彙知識の活用が不 可欠な自然言語文の推論処理に適しているが , 従来の表 現法では必ずしも十分とは言えない，例えば「青年が外 国の企業て働く」という文は, “働く $(x$ :青年, $y$ :企業 $) \wedge$ 存 在する ( $y$ :企業, $z:$ 外国)”と表現することとなる .この場 合 , 名詞句「外国の企業」の中の助詞「の」の意味を「存 在する」と識別する必要があるが，弚の自動変換は容易 ではない．また，これを避けるため「の」の意味を識別 せずに , “働く $(x$ :青年, $y$ :企業 $) \wedge$ ( $y$ :企業, $z:$ 外国 $) ” の$ 
ように表現することも可能であるが, 名詞句の構造が複 杂隹な場合には見通しの良い (弚の表現を見て意味が分か りやすいという意) 表現法とは言えない .

また，表現能力に関しても，例えば「太郎は花子が読ん だ本を買った」も「花子は太郎が買った本を読んだ」も， “買う (太郎: $丁, a$ :本)^読む (花子: $\top, a$ :本)” と同一の表現 になってしまう．すなわち，時制論理の概念を導入しな いと，従来の表現法では「読む」と「買う」との前後関

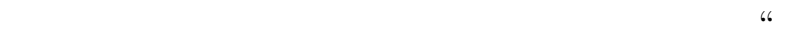
う (太郎: $\top, f_{1}$ (花子: $丁$ ):本)”, “読む (花子: $\top, f_{2}($ 太郎: $丁$ ): 本)”と表すことも可能であるが、これらも見通しの良い 表現とは言えない(ここで関数 $f_{1}(x) 、 f_{2}(x)$ は, 弚れ光 れ “ $x$ か読んだ本” , “ $x$ が買った本”を意味する). 関数 と構造を持ったソートとの本質的な違いは 6 章で述べる .

これら問題は，従来の順序ソート論理においては名詞 句のような構造を持ったソートを扱えない(扱う場合は ひとつの概念として定義) ことに起因する.すなわち，こ れを扱えるように拡張すれば，最初の例文は “働く $(x$ :青 年, $y:[z:$ 外国] の企業)”と表すことができる .また，後の例 文は, 従属節の部分を述語式 (真偽ではなく修飾的機能) で表し，乥れにより修飾された名詞概念をソートに用い

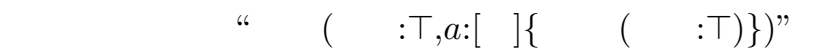
“読む (花子:丁, $a:[$ 本] $\{$ 買う (太郎: T) $\})$ ”と表される.す なわち，このように構造を持ったソートを許容すると，単 文だけでなく複文も正確にかつ見通し良く表現可能とな る.また，意味解析が難しい名詞句を知識表現上一緾ま りとして扱うと，自動変換上も有利である．WPL はこ のような表現を可能とする知識表現法である .

\section{$2 \cdot 2$ WPL の表現対象}

WPL では以下の条件を満たす自然言語文を表現対象 とする.

(1)主語・述語の明確な文

(2)文の表現主体からは独立な，対象にかかわる文

(1)は, 自然言語処理ツールによる自動変換を意識して いるため, 当然の条件である.また，(2)は，変換された 知識を推論処理で使うことを想定しているため, 文の表 現主体にかかわる文は有用性が少ないと考えられるから である.以下これについて簡単に説明する。

文献 [益岡 00] では, 文は光の表現主体から独立した 対象にかかわる文と表現主体にかかわる文とに分けられ， さらに，前者は一般的な事態を表す文と個別的な現象を 表す文に，一方後者は主体の判断を表す文と事態あるい は判断を表現・伝達する文に分けられるとしている．こ

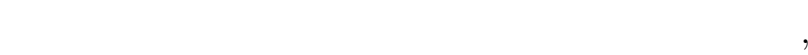
「判断のレベル」,「表現・伝達のレベル」と呼び，こうし た文のまとまりを支える概念の諸段階を「文の概念レベ ル」と呼んでいる.これら概念レベルの文を例示すれば， 弚れ光れ「春は雨が降る」,「昨日は雨が降った」,「今
日は雨か降るだろう」,「昨日は雨か降ったようだよ」と いった文が挙げられよう．この例から分かるように，事 態命名のレベルの文は, クラス・インスタンスの関係で 考えればクラスに相当し，現象のレベルの文はインスタ ンスに相当する．この種の文は知識化したとき，一般に 前者は規則的知識 (問題知識) として, 後者は事実知識と して推論処理において利用できることは明かである．ー 方, 残りの 2 つの概念レベルの文は, 各種の問題解決を 主目的とする推論処理では, 不可能とは言えないまでも 有用性は少ないと言えよう.よって，ここでは表現対象 を(2)の文 , すなわち, 事態命名のレベルの文と現象のレ ベルの文に限定する .

\section{$2 \cdot 3$ WPL $の$ 構 成}

WPL は, 一つの文 (単文および複文) を定義 1 に規定 する一つの述語式により表す, 順序ソート論理ベースの 知識表現法である. 弚の述語式中のソートは定義 2 で規 定されるソート概念である . また，WPLでの論理式は一 般的な一階述語論理の場合と同樣に, 述語式を連言, 選 言, 含意等の論理演算子で結合し, 全称限量子, 存在限 量子で量化したものである .

(1) 述語式

[定義 1] $P$ を述語， $t_{i}$ を引数 (項),$r_{i}$ を述語に対す る引数の関係を表すラベルとしたとき, 以下のように表 現された式 $L$ を述語式という .

$$
L=P\left(r_{1}: t_{1}, r_{2}: t_{2}, \cdots \cdots \cdots, r_{n}: t_{n}\right)
$$

ここで, 引数 $t_{i}$ は, $S_{i}$ をソート, $x_{i}$ を変数,$c_{i}$ を定数 としたとき，以下のように表現される .

$$
t_{i}=x_{i}: S_{i} \quad \text { or } \quad c_{i}: S_{i} \text { or } x_{i}: \top \text { or } c_{i}: \top
$$

この述語式において, 述語部 $P$ には動詞, 形容詞, 名 詞のいずれかを用い, 名詞の場合には关れが個体を示し 得る場合には次に定義するソート概念 $S$ を用いる(この場 合の述語式を以下, ソート述語と呼心゙）。 また，ラベル $r_{i}$ は述語部の品詞により異なり，動詞の場合は agt(主格)， obj(対象格), plc(場所格) 等の深層格 (主にEDR 辞書で 用いられているラベルを想定)を，形容詞や名詞の場合 は sbj , inst のような新たに設定したラベルを用いる [石 川 04] .

引数 $t_{i}$ は, 以上に定義したようにソート付の変数また は定数であるが, この定数には固有名詞を含めることと する．すなわち，固有名詞は個体の識別子であるから定 数の一種として扱う.例えば，太太郎」という固有名詞は“ 太郎：丁”と表す(ソートが分かっている場合は丁でなく 乥れをソート概念として用いる).なお，従来の順序ソー 卜論理では引数に関数を用いることができるが, WPL では定義 2 の構造を持ったソート概念により表現できる ため, 基本的には不要である (関数を利用する場合には 
定義 1 の変数, 定数を関数とみなせばよい. 3 章の推論 法は関数の使用をも想定したものである).

(2) ソート概念

[定義 2] 以下の構成から成る概念を谷れ光れ, 基本 概念 $(w)$, 節付概念 $\left(w_{p}\right)$ ，個体概念 $\left(g_{s}\right)$ ，複合概念 $(G)$ ， ソート概念 $(S)$ と呼ぶ.

$\cdot w=(\text { 副詞 } o r \text { 形容詞 } o r \text { 名詞 })_{* 0}+$ 名詞

- $w_{p}=[S]\left\{L_{p}\right\}$

- $g_{s}=[x: S]$ or $[c: S]$ or $[x: \top]$ or $[c: \top]$

$\cdot G=(\text { 修飾概念 }+ \text { 助詞 })_{* 1}+$ 主概念

ここで, 修飾概念 $=w$ or $w_{p}$ or $g_{s}$ 主概念 $=w$

- $S=w$ or $w_{p}$ or $G$

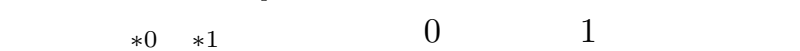
返しを表す．また， $L_{p}$ は複文における従属節を表すため の述語式 (以下, 節述語と呼ぶ) であり，構成上は定義 1 の述語式 $L$ と同一である．ただし，Lは“真”または “ 偽”を弚の值とするが, $L_{p}$ は従属節で述べられている現 象や情況等の事柄を表わす.

この定義中の各概念はすべて個体を示し得る概念であ り，基本概念は名詞単語または複合語である．形容詞等 で修飾された名詞もこれに含める．節付概念は，従属節 により修飾された概念を表すための形式で， $L_{p}$ および光 れにより修飾されるソート概念 $S($ この部分を先行詞部と 呼ぶ）よりなる．例えば，「青年が買った本」では，「本」 が $S$ で，「青年が買った」が $L_{p}$ により表される．

また , 複合概念は，いわゆる名詞句一般を表すための 概念であり，修飾概念と助詞の繰り返し(修飾部)と炎れ により修飾される主概念よりなる．助詞は「の」「から」， 「の」等々名詞の連結に用いられるものなら何でもよい． ここで, 主概念は, 弚の名詞句の大本の概念であり, 基 本概念 $w$ に限定する . 例えば，「社長の船の模型」という 名詞句では，「模型」が主概念である．一方，修飾概念は， 基本概念 $w$ や節付概念 $w_{p}$ の一般的な概念 (以後, 複合 概念を含めこれらを一般概念と呼ぶ）だけでなく，特定 の個体を指している場合もある . 後者の場合をここでは 個体概念 $g_{s}$ と呼ぶ . この個体概念はソート付の変数また は定数であり，表現上は述語式の項と同一である .

ソート概念 $S$ は, 基本概念 $w$, 節付概念 $w_{p}$, 複合概念 $G$ のいずれかであり, 以上から分かるように再帰的な構造 をとる.これは, 名詞句の意味が先れを構成する概念 (語 彙) が何を指しているかにより大きく異なるからである . 例えば, 先の名詞句は, “ $\left[c_{1}\right.$ :社長 $]$ の船の模型”, “ $\left[c_{1}\right.$ :社 長 $]$ の $\left[c_{2}\right.$ :船 $]$ の模型” , “ $\left[c_{2}:\left[c_{1}\right.\right.$ :社長 $]$ の船 $]$ の模型” 等々 と表現され得る. 弚れ光れ，“社長である太郎の普通の船 の模型” , “社長である太郎の戦艦大和の模型” , “社長で ある太郎が所有するタロー号の模型”を指すような場合 である .すなわち, 名詞句の意味は, 助詞の意味だけで なく，光れを構成する名詞が一般的な概念を指すか特定 の個体を指すかにより異なってくる．ただし，個体概念 $[x: S]$ における $S$ の中には変数 $x$ は含まないとする . 無 限にループすることになり $S$ が定まらないためである .

\section{$2 \cdot 4$ 具体的な表現法}

ここでは，WPLによる自然言語文の具体的な表現法， 表現例，表現範囲について述べる.

\section{$\S 1$ 表現法と表現例}

(1) 単文

述語式の形式は, 対象となる文の述部の品詞により決 定する . 具体的には述部となる品詞には動詞 , 名詞 (“... である”の文型)，形容詞があり，述語式では光れらを述 語部とし，光れ毎に異なる引数のラベル付けを行う.以 下に表現例を示す.

(1)“太郎は車の鍵を探している”

$\Rightarrow$ 探す (agt : 太郎: $\top$, obj : $c_{1}:\left[c_{2}:\right.$ 車 $]$ の鍵 $)$

(2)“太郎は田舎の医者である”

$\Rightarrow\left[c_{1}:\right.$ 田舎 $]$ の医者 (inst：太郎:丁)

(3)“太郎は優秀である” $\Rightarrow$ 優秀 $(\mathrm{sbj}:$ 太郎: $\top)$

(4) “花子は美しい”

$$
\Rightarrow \text { 美しい }(\mathrm{sbj}: \text { 花子: } \top)
$$

述語部が動詞の場合には(1)のように引数には深層格を とる . 名詞の場合には , 乥れが個体を示し得るソート概 念の場合には(2)のようにラベル inst を用い , 特性を表す 概念 (主に形容詞を名詞化したような概念) の場合には(3) のようにラベル sbj を用いる . また , 形容詞の場合には , 基本的にはラベル sbj を用い(4)のように表す . 述部が形 容詞となる文にはとの他多くの文型があるか詳細は文献 [石川 04]を参照されたい.

\section{(2) 複文}

複文は, 名詞節，連体節，連用節，並列節に分類され る従属節と主節とよりなる。ここでは, 従属節が名詞節， 連体節，連用節 (条件文を除く) の場合は文全体を一つの 述語式で表現する.これら従属節は前述のように $L_{p}$ で 表し, 先行詞部を付加した節付概念 $w_{p}$ の形で, 主節を 表す述語式の述語部あるいは引数部の一部として埋め込 んで表現する .一方，並列節の場合は，意味的には主従 の関係を持つことが少なく，主節と従属節を光れ独 立の文として扱ってよい場合が多い．したがって，節毎 に述語式を用いて表し，文全体としては光の連言で表す．

また，節述語が名詞を修飾している場合は，被修飾名 詞と述語部の動詞とは格関係で意味的に連結されている 場合が多い。したがってこの場合には， $L_{p}$ 中の対応する ラベルの引数部に格関係の存在を示す記号 “\#”を記すこ ととする．以下に表現例を示す．

(1) “刑事は犯人か隠れている家を探している” $\Rightarrow$ 探す $\left(\right.$ agt : $c_{1}$ :刑事, obj : $c_{2}:[$ 家 $]\left\{\right.$ 隠れる (agt : $c_{3}:$ :犯, plc: \#)\})

(2) “花子は太郎が犯人である事実を知っている” $\Rightarrow$ 知る (agt : 花子: $\top$, 
obj : $c_{1}:[$ 事実 $]\{$ 犯人 (inst : 太郎: $T$ ) $\}$ )

(3) “太郎は花子が帰宅するときに会社へ行く” $\Rightarrow$ 行く (agt : 太郎: $\top$, gol : $c_{1}$ :会社, tme: $c_{2}:$ [とき] $\{$ 帰宅する (agt:花子: $\top$, tme:\#)\})

(4) “花子は太郎が経営している会社の社員である” $\Rightarrow\left[c_{1}:[\right.$ 会社 $]\{$ 経営する (agt : 太郎: $丁$, obj:\#)\}] の社員 (inst：花子:丁)

(1)と(2)は従属節が連体節の場合である . 連体節は , 被 修飾名詞と連体節の述語との間に何らかの格関係が存在 する場合と，単に連体節が被修飾名詞の内容を表す等価 の関係の場合がある . (1)は前者の場合であり，節述語と 被修飾名詞である先行詞部との間にラベル plc(場所格) で格関係があるため乥こに\#を付している．これに対し (2は後者の場合であり，格関係が存在しないため節述語 内に\#は付さない，(2)の例文において「事実」が「こと」 や「の」に変わると名詞節となる．名詞節は節全体が名 詞として機能する．したがって，節述語で名詞節を表せ ば先行詞部は不要となるが, 後述する推論処理の都合上, 形式的に概念「こと」を先行詞部に置く．(3)は連用節の 場合であり，時間格 (ラベル tme) として表現すれば先行 詞部は不要となるが, 同樣に概念「とき」を先行詞部に 置く . (4)は従属節が述語式の引数部でなく述語部で表現 される例である

以上は, 文が個別的な事象を表す (知識化したとき事 実知識となる) 場合の表現例であるが , 一般的な事象を 表す (問題知識となる) 場合には, 基本的には以下のよう に個体を示す定数 $\left(c_{i}\right)$ を変数 $\left(x_{i}\right)$ に置き換えればよい.

(5) “都会の会社で働く労働者は裕福である”

$\Rightarrow$ 裕福 $\left(\operatorname{sbj}: x_{1}\right.$ :[労働者] $\{$ 働く (agt：\#, plc : $x_{2}:\left[x_{3}\right.$ : 都会 $]$ の会社 $\left.\left.)\right\}\right)$

なお, 述語式中の引数のラベルおよび\#は, 説明上必 要な場合以外は記述が複雑になるため以後省略する .

\section{$\S 2$ 表現範囲}

2.2 節で述べた表現対象とする文のうち WPL で表現 できるのは, 定義 2 のソート概念を用いて定義 1 の述語 式で表現できるすべての文である (自動変換の可能性は 別問題) .したがって, 前節の表現例からも分かるように 表現対象とするほとんどの文（個体についてだけ述べた すべての文) が扱える．また，当然これらについては提 案する推論法ですべて処理できる.

WPL で表現できない (あるいはしずらい) 文は , 個体 の性質あるいは個体間の関係についての陳述ではない文 である .これはWPL 特有の問題ではなく従来の順序ソー 卜論理さらには一階述語論理でも同樣である．前にも述 べたように，真偽を問題とする論理と情報伝達を目的と する自然言語とは本質的に相容れない面があるからであ る.このような文としては，例えば，“太郎は医者にな るために勉強する”のような文 (個体についてでなく目 的について述へている) が挙げられよう．この文を強引 にWPL で表せば，“勉強する (agt : 太郎: T , gol : $c_{1}$ : [目
的] $\left\{\right.$ なる $\left(\mathrm{agt}:\right.$ 太郎: $\top$, gol $: c_{2}:$ 医者 $\left.\left.)\right\}\right) "$ となる「目的」 も個体の一つと言えないこともないが若干不自然さがあ る(“太郎は食べるために働く”のような文ではもっと不 自然).さらにこの種の文を提案する推論法で処理すると 直感とずれた結果がでるという問題もある $(6$ 章 (3) を 参照) .

また，量等に関する等値関係を述べた文もWPL には 適さない(当然従来の順序ソート論理でも同樣).例えば， “男性の平均身長は $170 \mathrm{~cm}$ である”は, WPL で表弚うと すれば “等值 (atr: $c_{1}$ : 男性の平均身長, val $\left.: 170 \mathrm{~cm}: \top\right)$ ” と なり，あまり自然な表現とは言えない，さらに，このよう に知識化しても，“人間の平均身長は $170 \mathrm{~cm}$ である” を知 識化したものとの照合か取れるわけでもない(“男性 $\subseteq 人$ 間”というサブソート関係を推論で利用できない)．すな わち，こういった関係を述べた文は，例えば “等値 (atr : 男性の平均身長, $\mathrm{val}: 170 \mathrm{~cm})$ ” と一般の一階述語論理 で表し, 推論も关の枠組みで行うべきと言える (WPL と 混在しても推論時に別個に扱えば問題はない).

\section{3. 推 論処 理 法}

\section{$3 \cdot 1$ 基本的な考え方}

WPL で表現された知識に対する推論法の基本的なメ カニズムおよび本手法のベースとなる Beierle らにより 提案された推論規則 [Beierle 92] について説明する.

(1) 推論メカニズム

推論処理は図 1 に示すような導出処理を繰り返し用い ることで行う.この処理の基本的な考え方は，2つの親 節 $\neg A \vee B$ と $A^{\prime} \vee C$ から,$A$ と $A^{\prime}$ が単一化可能または $A$ が $A^{\prime}$ を意味的に包含しているならば導出節 $B \vee C$ を 導き(図 1(a))，あるいは，弚のようになるための $\neg A ，$ $A$ に含まれるソート間の条件 $S$ をこれに付加して導出 節とする(图 1(b)) というものである.すなわち，ある 条件が成立すれば推論を進められる場合, 弚の条件を導 出節に付加して推論を進めるという考え方である．した がって, 条件 $S$ は処理の綝延心項として機能することに なる.例えば， $A$ と $A^{\prime}$ が弚れ光れ “賢い(太郎:丁)”, “賢 い $(x$ :青年)” の場合, “青年 (太郎: T)”が $S$ となる .こ の場合，この知識 $S$ が存在すれば $A$ と $A^{\prime}$ は単一化可能 となるので, これらを消去し， $S$ を導出節として推論を 進めることになる.Beierle らはこの条件 $S$ (以下，SL 節

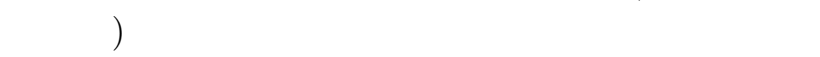
案している。

本推論法は, この推論規則を 3.2 節のような構造を持っ たソートを扱えるよう拡張したものである .さらに , 従 来の順序ソート論理では, 弚こで用いられる各ソートの サブソート関係 (ソート階層) が定義されているが (言語 の定義に含まれる)，WPL におけるソートは無数の構造 (名詞句) カ採り得るためすべてを定義しておくのは非現 実的と言える (対話システムへの応用等では不可能).し 


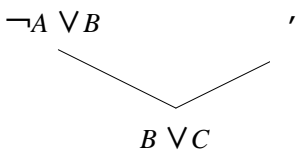

(a) $A$ と $A^{\prime}$ が単一1 能又は意味的に $A^{\prime} \subseteq$, 場合

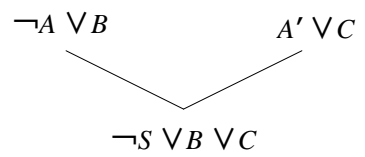

(b) 条件 $S$ のもとで, $A$ と $A^{\prime}$ が単一化可能又は意味 的に $A^{\prime} \subseteq A$ の場合
図 1 推論処理の基本的な考え方

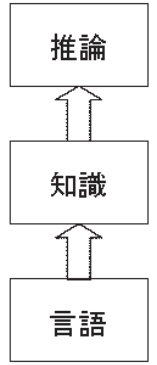

(a) 従来の論理

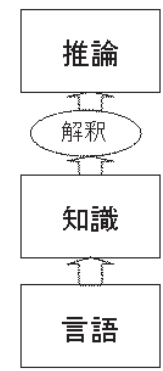

(b) 本推論法
図 2 本推論法の枠組み

たがって，従来の推論処理では前述の意味的な判定を光 の定義に基づき直接行えばよいが, 本推論法では構造化 されたソートの意味を予め定めた規則の下に解釈しなが ら弚の判定を行う．すなわち，図 2 に示すように，従来 の論理では言語を定義し光れに基づいて知識を書き下し 乥れを用いて推論するが, 本推論法では知識中のソート の意味を解釈しながら推論する枠組みとなる . 自然言語 文を対象とし具体的な応用を意識した場合，必然的に同 图の枠組みなると考えられる .

(2) Beierle らの推論規則

Beierle らは前述の SL 節 $(S L(\sigma))$ を以下のように定 めている .

$$
\begin{array}{r}
S L(\sigma)=\bigwedge\left\{S_{i}(\sigma(x)) \mid \operatorname{sort}(\sigma(x)) \nsubseteq \operatorname{sort}(x),\right. \\
\text { where } \left.x \in \operatorname{dom}(\sigma), S_{i}=\operatorname{sort}(x)\right\}
\end{array}
$$

ここで, $\sigma$ は単一化における代入, $\operatorname{sort}(x)$ は代入される 変数 $x$ のソート, $\operatorname{sort}(\sigma(x))$ は代入結果 (代入する側) の ソート, $\operatorname{dom}(\sigma)$ は代入 $\sigma$ に関する変数のドメインであ る.また, ^は連言を表す.本来，単一化における代入は， 代入する側のソートが代入される側のソートのサブソート の場合 (well-sortedness) のみ適切な代入であることが保 証される.これに対し，光うでない場合 (ill-sortedness) にも個体が両ソートに共通に属する場合があるので，光 れを定式化したのが SL 節といえる .すなわち，SL 節は， 変数 $x$ への代入結果のソートが $x$ のソートのサブソート
でない $(\operatorname{sort}(\sigma(x)) \nsubseteq \operatorname{sort}(x))$ ときに,$x$ のソートを述 語部, 弚の代入結果を引数とするソート述語 (代入される 変数が複数ある場合は产のソート述語の連言)である . 例 えば, $P\left(x_{1}: S_{1}, x_{2}: S_{2}\right)$ と $P\left(c_{1}: S_{1}^{\prime}, c_{2}: S_{2}^{\prime}\right)$ の単一化 では, $\sigma=\left\{x_{1}=c_{1}, x_{2}=c_{2}\right\}, \operatorname{dom}(\sigma)=\left\{x_{1}, x_{2}\right\}$ であ り, $S L(\sigma)=S_{1}\left(c_{1}: S_{1}^{\prime}\right) \wedge S_{2}\left(c_{2}: S_{2}^{\prime}\right)$ となる $\left(S_{1}^{\prime} \nsubseteq S_{1}\right.$, $S_{2}^{\prime} \nsubseteq S_{2}$ の場合)

このSL 節を用い, "EOS resolution rule(EOS), Subsort resolution(SUBS), Elimination rule(ER)" と呼ば れる 3 つの推論規則が以下のように定式化されている.

$$
\text { EOS : } \quad \frac{\neg L_{1} \vee A, L_{2} \vee B}{\sigma(A \vee B) \vee \neg S L(\sigma)}
$$

ここで, $L_{1}$ と $L_{2}$ は述語部が同一の素式である .

$$
S U B S: \quad \frac{\neg S_{1}\left(t_{1}\right) \vee A, S_{2}\left(t_{2}\right) \vee B}{\sigma(A \vee B) \vee \neg S L(\sigma)}
$$

ここで, $S_{1}\left(t_{1}\right)$ と $S_{2}\left(t_{2}\right)$ は $S_{2} \subseteq S_{1}$ であるソート述語， $\sigma$ は項 $t_{1}, t_{2}$ 間の代入である

$$
E R: \quad \frac{\neg S_{1}\left(t_{1}\right) \vee A}{\sigma(A) \vee \neg S L(\sigma)}
$$

ここで， $S_{1}\left(t_{1}\right)$ はソート述語， $\sigma$ は項 $t_{1}$ に関する代入， また $\operatorname{sort}\left(\sigma\left(t_{1}\right)\right) \subseteq S_{1}$ である.

EOS は，述語部が同一の素式 $L_{1}$ と $L_{2}$ とを含む親節 間における推論規則であり，融合における最も基本的な 規則である.SUBS は, 単一化する部分 $S_{1}$ と $S_{2}$ が共に ソート述語の場合の規則であり， $S_{2}$ が $S_{1}$ のサブソート の場合に適用される．ERは，代入処理後のソート述語を 消去するための規則であり，代入を行った結果のソート が述語部のソートのサブソートの場合に適用される．な お，これら規則の適用において, $\operatorname{sort}(\sigma(x)) \subseteq \operatorname{sort}(x)$ の場合には $\sigma$ は適切な代入 (well-sortedness) であり，当 然導出は行われるが SL 節は生成されない .

\section{$3 \cdot 2$ 推論規則の拡張と適用法}

前節で示した推論規則を，一般的には変数を含む名詞 句となる定義 2 のソート概念を扱えるように拡張する． この場合，述語式を一般的に表すと以下のようになる. 述語部 $P$ に変数 $z$ が含まれるのはソート述語の場合であ る.また , ソート述語は単項述語とする.

$$
L=P[z]\left(x_{1}: S_{1}[y], x_{2}: S_{2}[y], \cdots \cdots \cdots\right)
$$

この一般式において $, y=\left\{y_{1}, y_{2} \cdots\right\}, z=\left\{z_{1}, z_{2} \cdots\right\}$ とし, 各変数の包含関係について規定する . まず, 変数 $x_{i}$ と $y$ の関係については, 2.3 節の最後で述べたように $S_{i}$ の $y$ が $x_{i}$ を含むことは禁止する .ただし , 他の引数 のソート $S_{j}$ が変数 $x_{i}$ を使うことはあり（次の $\mathrm{EOS}$ の 適用例を参照) , “ $x_{i} \in S_{j}$ の $y$ ” の関係は許容する . また， $y$ と $z$ の関係については, 同じ変数を用いて $P$ や $S_{i}$ を 記述することはごく普通に起こるため) (後の SUBS の適 


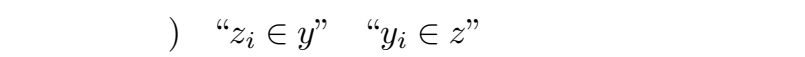
方, 変数 $x_{i}$ と $z$ の関係については, $z$ が $x_{i}$ を含むこと は禁止する.$P[x](x)$ は意味的に $x: P[x]$ と等価である からである。

規則の拡張においては, 単一化代入 (引数間での代入) において生成される SL 節の他に, ソート概念内の变数に 関する代入等の操作について規定することになるが， こ の際以上の変数の包含関係を考慮する必要がある .ここ ではまず規則の拡張に必要なSLp 節を以下のように定義 する .

[定義 3] 二つのソート概念 $S_{1}, S_{2}$ について,$S_{2} \subseteq S_{1}$ となり得るための， $S_{1} ， S_{2}$ 中の個体概念力涽す個体か満 たすべき条件 (ソート述語の連言)をSLp 節と呼ぶ .

例えば， “ $S_{1}=[x$ :社長 $]$ の船” , “ $S_{2}=[c$ :青年 $]$ の船” の 場合，青年である個体 $c$ が社長でもあれば， $S_{2} \subseteq S_{1}$ を 満たし得る．したがって，“社長 ( $c$ : 青年)”がSLp 節とな る.この SLp 節については次章て詳述するが , 3 つの推 論規則のうち SUBS と ER はこれを用いて拡張される.

\section{$\S 1$ EOS}

EOS は, 以下に示すように基本的に前節の式 (3) と同 じである .

$[E O S]: \quad \frac{\neg L_{1}{ }^{\prime} \vee A, L_{2} \vee B}{\sigma(A \vee B) \vee \neg S L(\sigma)}$

ただし，単一化の対象となる述語式 $L_{1}^{\prime}, L_{2}$ の述語部に ついては弚れらが同一であるか，前者の关れが後者の上 位概念であり，また引数部については前者の引数と同一 のラベルの引数が必ず後者にも含まれているとする .す なわち， $L_{1}^{\prime}$ と $L_{2}$ が同一の場合だけでなく前者が後者を 意味的に包含する場合を含むように拡張する．下位概念 で成り立てばその上位概念で成り立つことは当然であり， また，述語式において引数か増えることは光の意味をよ り限定することになるからこれは自然な拡張と言える．

また， $\sigma$ は午の単一化における引数間の代入であり， $S L(\sigma)$ は关の代入に伴い生成される SL 節である.これ は式 (2) から以下のように変更される .

$$
\begin{aligned}
S L(\sigma)= & \bigwedge\left\{S_{i}(\sigma(x)) \mid \sigma(\operatorname{sort}(\sigma(x))) \nsubseteq \Phi(\operatorname{sort}(x))\right. \\
& \text { where } \left.x \in \operatorname{dom}(\sigma), S_{i}=\sigma(\operatorname{sort}(x))\right\}
\end{aligned}
$$

式中の記号の意味は式 (2) と同樣である.SL 節の生成 条件 (| の右側の式) と $S_{i}$ が, 前述したように代入 $\sigma に$ 関する変数がソート内に含まれることがあるため, 変更 されている .

EOS の具体的な適用法について例を用いて説明する . 式 (7) において, $A=B=0$ で， $L_{1}^{\prime}$ と $L_{2}$ が光れぞれ， “働く $\left(x_{1}\right.$ : 青年, $x_{2}:$ [企業 $]\left\{\right.$ 営む $\left(y_{1}:\left[x_{1}\right.\right.$ : 青年 $]$ の親戚 $\left.\left.)\right\}\right)$ ” と “働く $\left(c_{1}\right.$ : 専門家, $c_{2}:[$ 会社 $]\left\{\right.$ 営む $\left(c_{3}\right.$ : 政治家 $\left.\left.)\right\}\right)$ ” とし よう.この場合， $\sigma=\left\{x_{1}=c_{1}, x_{2}=c_{2}\right\}$ であり，第一引 数の变数 $x_{1}$ が第二引数のソートに含まれているため光 の代入も行われ，
“ $S L(\sigma)=$ 青年 $\left(c_{1}\right.$ : 専門家 $) \wedge$ [企業 $]\left\{\right.$ 営む $\left(y_{1}:\left[c_{1}\right.\right.$ : 専門家 $]$ の親戚 $)\}\left(c_{2}:\right.$ :会社 $]\left\{\right.$ 営む $\left(c_{3}\right.$ : 政治家 $\left.\left.)\right\}\right) "$

となり， $A=B=0$ なのでこの SL 節が導出節となる.

なお， $\sigma$ と関係しない変数に関してはソート間では代 入 (先の例では $y_{1}$ への $c_{3}$ の代入) は行わない . SL 節と 単一化可能な知識が存在した場合, 光れを用いて产のま ま推論を進められるからである．弚れが存在しない場合 には, この代入は後述する ER の段階で行われることに なる.すなわち, EOS では引数自体の変数に関する代入 ののみを行い, ソート内の変数に関しては乥れが引数の 変数でもある場合のみ同代入が行われる.また, 当然式 (7) 中の $A, B$ 内のソートの変数についてもこの代入 $\sigma$ は行われる .

\section{$\S 2$ SUBS}

SUBS は定義 3 の SLp 節を加え以下のように拡張さ れる。

$[S U B S]: \quad \frac{\neg S_{1}\left(t_{1}\right) \vee A, S_{2}\left(t_{2}\right) \vee B}{\sigma \sigma_{p}(A \vee B) \vee \neg S L\left(\sigma \sigma_{p}\right) \vee \neg S L p}$

ここで, $S_{1}, S_{2}$ が単一化の対象となるソート述語である. $\sigma$ はその単一化における引数間の代入であり， $\sigma_{p}$ は $S_{1}, S_{2}$ のみに含まれる変数に対する代入である. $S L\left(\sigma \sigma_{p}\right)$ は代 $\lambda \sigma, \sigma_{p}$ に伴い生成される SL 節である.また,$\sigma \sigma_{p}(x)$ は $\sigma\left(\sigma_{p}(x)\right)$ を意味するが, 本節の冒頭で述べた変数の包含 関係から $\sigma$ と $\sigma_{p}$ は互いに独立な代入となり， $\sigma \sigma_{p}(x)=$ $\sigma_{p} \sigma(x)$ である.SUBS は本来， $S_{2} \subseteq S_{1}$ の場合に適用さ れる規則であり，上式は弚うなるためのソートの条件で あるSLp 節の否定を導出節に付加したものである．

また，SUBS では SL 節は以下のように表される.

$$
\begin{aligned}
S L\left(\sigma \sigma_{p}\right) & \\
= & \bigwedge\left\{S_{i}(\sigma(x)) \mid \sigma_{p}(\operatorname{sort}(\sigma(x))) \nsubseteq \sigma_{p}(\operatorname{sort}(x))\right. \\
& \text { where } \left.x \in \operatorname{dom}(\sigma), S_{i}=\sigma_{p}(\operatorname{sort}(x))\right\}
\end{aligned}
$$

記号の意味はこれまでと同樣であり，式 (8)の $\sigma$ の一 部が $\sigma_{p}$ に置き換わった形になっている . 式 (6)において $z_{i}$ が $y$ に含まれることがあるためである .

SUBS の具体的な適用法について説明する . 式 (9)に おいて,$A=B=0$ で, $S_{1}$ と $S_{2}$ が产れ午れ，“[ $z_{1}$ :会社 $]$ の後継者 $\left(x_{1}:\left[y_{1}:\left[z_{1}\right.\right.\right.$ :会社] の社長] の子供)” と“[日芝: $\left.丁\right]$ の後継者 $\left(c_{1}:\left[c_{2}:\right.\right.$ [日芝: $\left.丁\right]$ の重役] の親戚)" としよう.こ の場合， $\sigma_{p}=\left\{z_{1}=\right.$ 日芝 $\}, \sigma=\left\{x_{1}=c_{1}\right\}$ であり，こ れらを式 (10) に適用すると SL 節は，

“ $S L\left(\sigma \sigma_{p}\right)=\left[y_{1}:\right.$ [日芝: $\left.T\right]$ の社長] の子供 $\left(c_{1}:\left[c_{2}:[\right.\right.$ [芝: $\top]$ の重役] の親戚)"

となる。一方，SLp 節については， $\sigma_{p}$ が適切な代入であ るためには個体 “日芝”が $z_{1}$ のソートに属している必要 がある・したがって，

“SLp=会社 (日芝: $丁) "$ 
となり， $A=B=0$ なのでこれら SL 節と SLp 節の連言 か真出節となる。

SUBS は前述したように， $S_{2} \subseteq S_{1}$ の場合に適用され る規則であるから，これらに対しすべての代入操作 $(\sigma$ と $\sigma_{p}$ および次章で述べるみなし代入) を行ってもこの関係 が満たされない場合には適用されない，また，EOS の場 合と同樣に, 引数のソートにおいては $\sigma_{p}$ 以外の代入は 行わない (この例では $y_{1} に c_{2}$ を代入しない) .

\section{$\S 3$ ER}

ER は以下のように拡張される .

$$
[E R]: \quad \frac{\neg S_{1}(t) \vee A}{\sigma \sigma_{p}(A) \vee \neg S L\left(\sigma \sigma_{p}\right) \vee \neg S L p}
$$

ここで， $S_{1}$ が消去対象のソート述語であり， $\sigma$ は光の 項 $t$ に対する代入， $\sigma_{p}$ は光の代入結果のソートと $S_{1}$ 間 での代入である. $S L\left(\sigma \sigma_{p}\right)$ は, 代入 $\sigma, \sigma_{p}$ に伴い生成さ れる SL 節であり，式 (10) と同じ式となる . ER は本来， $\operatorname{sort}(\sigma(t)) \subseteq S_{1}$ の場合に適用される規則であり，SLpは 谷の関係を満たすための条件であり，SUBS の場合と同 じように生成される。

ER の具体的な適用法について説明する . 式 (11)にお いて $, A=0, S_{1}=\left[z_{1}\right.$ :先進国 $]$ の閣僚 $\left(x_{1}:\left[z_{1}\right.\right.$ :先進国 $]$ の 財閥) で, 変数 $x_{1}$ に対して “ $x_{1}=c_{1}$ :[日本:丁] の閣僚” が 代入 $(\sigma)$ されたとしよう.この場合 $\sigma$ により， $S_{1}$ は“ “ $\left[z_{1}\right.$ : 先進国] の閣僚 $\left(c_{1}:\right.$ [日本: $\left.\top\right]$ の閣僚)”となり，“[日本: $\left.T\right]$ の閣僚 $\subseteq\left[z_{1}\right.$ : 先進国 $]$ の閣僚”なら真となり消去される . このためには, $\sigma_{p}=\left\{z_{1}=\right.$ 日本 $\}$ が適切な代入となる必 要があり, SLp 節は以下のようになる .

"SLp=先進国 (日本: $T) "$

また，SL 節は以上の代入 $\sigma, \sigma_{p}$ により，

" $S L\left(\sigma \sigma_{p}\right)=$ [日本:丁] の財閥 $\left(c_{1}:\right.$ [日本: $\left.丁\right]$ の閣僚)" となり， $A=0$ なのでこれらの連言が導出節となる．

ER も SUBS と同樣に, $\operatorname{sort}(\sigma(t)) \subseteq S_{1}$ か満たされな い場合は適用されない．また，代入 $\sigma$ を行わず代入 $\sigma_{p}$ だけを行ってソート述語 $S_{1}$ を消去してもよい，光の場 合は当然 SL 節は生成されない．

ER は，主に EOS ゃ SUBS の適用で生成された SL 節やSLp 節を消去するための規則とも言える．したがっ て, 実際の推論処理ではまず EOSや SUBS を先に適用 し，弚の後に关の導出節に対してこの適用を行うことに なる、ただし，EOSやSUBS の適用の直後ではなく，光 こで発生する SL 節が直接満たされない (知識中に光れと 同じ節がない)ことを確認した後に適用すべきである．

\section{4. サブソートの判定法と SL p 節の生成法}

\section{$4 \cdot 1$ サブソート 関係の判定法}

サブソート関係は, ソートである概念間の意味的な包 含関係 (包捸) である．3.1節で述べたように，本推論法 では構造を持ったソートのサブソート関係は未定義であ
り推論プロセスの中で判定を行う .この判定はソートに 対する一種の解釈とみなされるが, 名詞句の意味解析が 難しいことから，乥の完璧性の追求は非現実的と言える . ここでは，以下の仮定の下での判定基準を提案する.

(1) 助詞を含めすべての概念は同じ表記であれば同じ 意味を持つ

(2) 概念 $a, b, c, d$ において, $\operatorname{sort}(a) \subseteq \operatorname{sort}(c)$ かつ $\operatorname{sort}(b) \subseteq \operatorname{sort}(d)$ のとき $\operatorname{sort}(a b) \subseteq \operatorname{sort}(c d)$.

ここで， $a b$ とは $a$ が $b$ を修飾していることを意味する. また， $\operatorname{sort}(g)$ は概念 $g$ のソートを表す．(1)は多義性は 扱わないということである . (2)は，概念 $a$ か概念 $b$ を修 飾するとき, $a$ は $b$ の意味範囲を限定する働きを持ち,$a$ の意味範囲が広ければ限定の度合いは小さく，狭ければ 大きくなるとの考えに基づいた仮定である．

定義 2 で示したようにソート概念 $S$ は基本概念 $w$ ，節 付概念 $w_{p}$, 複合概念 $G$ のいずれかであり，以下これら 毎のサブソート関係について考える .これら相互間につ いては, 修飾部分の意味に依存することが多く判定が微 妙になるため(例えば，“医者”と“偽の医者” の関係で は後者は前者のサブソートとは言い難い)，ここではサブ ソート関係は無いとして扱う。

\section{(1) 基本概念間}

複合語間については修飾部と被修飾部の関係が多樣で あるだけでなく慣用的な表現もあり，上記の(2)の仮定が 成り立たない場合が少なくない，例えば，“貿易会社”と “取引会社”，“上ラック会社”と“自動車会社”では，光

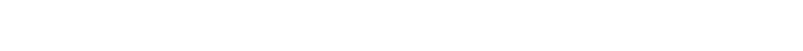
るいはサブソートであるが全体では光うならない .この ような関係は修飾概念が特性や動作を表す概念の場合に 多いが , 後者の例のようにごく一般的なソートに属して いてもあり得る．すなわち，複合語は慣用的な表現や造 語も多く，光の意味解析は一部 [竹内 02] を除き一般の名 詞句以上に難しいと言える .

したがって，ここでは複合語は単語と同樣に一つの概 念として扱う（サブソート関係が定義されていない場合 は光の関係はないとする) .なお, 単語間のサブソート関 係は全ての概念間の判定の基本となるが，これについて は予め定義 (シソーラス情報の利用も含め) されていると する .

\section{(2) 節付概念間}

節付概念 $[S]\left\{L_{p}\right\}$ は節述語 $L_{p}$ により先行詞部 $S$ を 修飾した概念であり，集合論的に見れば，ソート $S$ に属 する個体の集合を $L_{p}$ により限定したものである．した がって，一般的には(2)の仮定が成り立たつと考えられる さらに乥の関係は両者の間に存在する格関係を示す記号 “\#”のラベルにより識別可能であり，以下のような判定 基準か設定できる .ここで，比較する二つの節付概念を $w_{p_{a}}=\left[S_{a}\right]\left\{L_{p_{a}}\right\}, w_{p_{b}}=\left[S_{b}\right]\left\{L_{p_{b}}\right\}$ とする.また $L_{p_{a}}$, $L_{p_{b}}$ の述語部を弚れ光れ， $P_{a}, P_{b}$ とする. 


\section{·節付概念の判定基準}

以下をすべて満たしたとき， $\operatorname{sort}\left(w_{p_{a}}\right) \subseteq \operatorname{sort}\left(w_{p_{b}}\right)$.

i） 既定義あるいは複合概念の判定基準または本判定 基準により， $\operatorname{sort}\left(S_{a}\right) \subseteq \operatorname{sort}\left(S_{b}\right)$ かつ $\operatorname{sort}\left(P_{a}\right) \subseteq \operatorname{sort}\left(P_{b}\right)$ (述 語部が動詞の場合は $w_{p_{b}}$ 側が $w_{p_{a}}$ の上位概念).

ii) $L_{p}$ の引数部について, $w_{p_{b}}$ 側の引数と同一のラ ベルの引数が $w_{p_{a}}$ 側に含まれ，かつ炎れら引数が 同一個体を示す . また , 記号“\#”のラベルが同一．

i) は当然の条件であり，予め定義されている基本概念 間のサブソート関係あるいは次に示す複合概念の判定基 準を用い判定する．また，先行詞部がさらに節付概念の 場合は本判定基準を再帰的に適用する . ii) の最初の条件 は，引数の数が多い方がより限定的な意味となるからで あり，後の条件は，同一個体に関する節述語でないと先 行詞部に対する制限範囲が異なってくるからである

この基準では例えば，“[乗用車] $\left\{\right.$ 製造する $\left(c_{1}\right.$ :工員,\#,

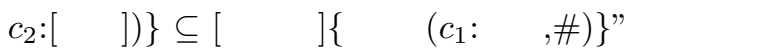

(3) 複合概念間

複合概念 $G$ は主概念を修飾概念と助詞の繰り返しによ り修飾した概念であり，助詞の多義性を無視すれば修飾 部と被修飾部の関係は一義的に定まることが多い．また， 複合語と異なり慣用的な表現も少ない．したがって，一 部の修飾概念を除いて(2)の仮定が基本的に成り立たつ.

また，複合概念では構成概念間の関係が複杂隹で，修飾 概念が後続の修飾概念を修飾し直接主概念を修飾しない 場合もある。したがって，厳密にはこの関係が解析でき ない限り全体のサブソート関係は判定できないが , ここ では比較する複合概念の構造が同一なら修飾関係も同一 と仮定する . 勿論，比較する複合概念間において，炎の 構成概念のあらゆる対応関係を求め，乥れ毎に推論する ことも不可能ではないが, 探索空間の爆発につながり実 用的とは言えないからである。

以上を考慮し , 複合概念間のサブソート関係について 以下のような近似的な判定基準を設定する．ここで，修 飾概念および主概念を $g$, 助詞を $p$ とし，比較する二つ の複合概念 $G_{a}, G_{b}$ を以下で表す.

$$
\begin{aligned}
G_{a} & =\left(g_{a_{1}}+p_{a_{1}}\right)\left(g_{a_{2}}+p_{a_{2}}\right) \cdots g_{a_{m}} \\
G_{b} & =\left(g_{b_{1}}+p_{b_{1}}\right)\left(g_{b_{2}}+p_{b_{2}}\right) \cdots g_{b_{n}}
\end{aligned}
$$

\section{・複合概念の判定基準}

以下のすべてを満たしたとき, $\operatorname{sort}\left(G_{a}\right) \subseteq \operatorname{sort}\left(G_{b}\right)$.

i) $G_{a}$ と $G_{b}$ が同数の修飾概念を持つ $(m=n)$.

ii）対応するすべての助詞が同一 $\left(p_{a_{i}}=p_{b_{i}}\right)$.

iii）修飾概念の中に修飾範囲を絶対的に限定できない 概念を含まない．

iv）対応するすべての修飾概念および主概念について $\operatorname{sort}\left(g_{a_{i}}\right) \subseteq \operatorname{sort}\left(g_{b_{i}}\right)$.

ただし , 修飾概念がともに個体概念の場合光れらが 示す個体が同一。 i）と ii) は構造が同一となるための条件である . iii) は 冒頭で述べた一部の修飾概念について規定したもので， 具体的には, すべての修飾概念は被修飾概念に依存せず かつ絶対的に個体を特定できる概念に限られるというこ とである . iii)に該当する概念としては , “大型” , “優秀” 等の特性 (主に程度) を表す概念が挙げられる．例えば， “大型の金魚”と “大型の魚” の関係では , “金魚” は“魚” のサブソートであるが全体では光うならない . “大型”と いう概念は被修飾概念に依存して相対的に关の範囲が定 まるからである. 文献 [兼岩 05] では概念の property 分 類を行っているが, 乥こでの準ソートや信念依存の概念 の一部がこの種の概念となる .

iv) は構成要素である修飾概念毎にサブソート関係が成 り立つという条件である . 修飾概念が節付概念の場合は 先の判定基準とこの判定基準とを繰り返し適用する . ま た , iv) の後半の条件は, 修飾する個体が異なれば限定さ れる範囲も異なることによる．この場合，個体が同一な ら当然光のソートの違いは判定に影響しない.

この基準では例えば， “ $\left[c_{1}\right.$ :女優 $]$ から $\left[c_{2}\right.$ :青年 $]$ への手 紙 $\subseteq$ 芸能人から $\left[c_{2}\right.$ :社長 $]$ への連絡”，となる.

ソート概念 $S$ のサブソート関係の判定は, 关れが再帰 的な構造をとる場合, 以上の 2 つの判定基準を比較する 概念の種類に応じて繰り返し適用して行うこととなる．

\section{$4 \cdot 2$ SLp 節の生成法}

$\mathrm{SLp}$ 節は定義 3 で示したように， $S_{2} \subseteq S_{1}$ あるいは $\operatorname{sort}(\sigma(t)) \subseteq S_{1}$ を満たすために, 光れらのソート概念中 の個体概念が示す個体が満たすべき条件として生成され る . 具体的には , 節付概念の判定基準の ii) の条件が引 数における変数の代入により，また複合概念の判定基準 のiv) の条件が個体概念間の変数の代入およびみなし代 入により満たされ，これらによりソート概念全体のサブ ソート関係が満たされるときに生成する．ここで，みな し代入とは，一般概念と個体概念間の比較において，光 の個体が一般概念に含まれるとする操作を言うこととす る.例えば，“若者の家”と“[太郎:丁] の家”というソー 卜間では, 若者 (太郎:丁) なら前者が示し得る個体の集合 は後者の乥れを包含することになる．ただし，みなし代 入は, $S_{1}$ 側が一般概念， $S_{2}$ あるいは $\operatorname{sort}(\sigma(t))$ 側が個 体概念の場合のみの操作とする (逆の場合は包含関係が 成り立たない）。

これらの代入が適切になる条件を述語式の連言として 表現したものが SLp 節であり，個体概念間の変数の代入 を $\sigma_{p}$, みなし代入における一般概念を $g_{b}$, 個体概念を $t: g_{a}$ としたとき，以下のように表される .

$$
\begin{array}{r}
S L p=\bigwedge\left\{S_{i}\left(\sigma_{p}(z)\right) \mid \sigma_{p}\left(\operatorname{sort}\left(\sigma_{p}(z)\right)\right) \nsubseteq \sigma_{p}(\operatorname{sort}(z))\right. \\
\text { where } \left.z \in \operatorname{dom}\left(\sigma_{p}\right), S_{i}=\sigma_{p}(\operatorname{sort}(z))\right\} \\
\bigwedge S_{i}^{\prime}(t) \quad \text { where } S_{i}^{\prime}=\sigma_{p}\left(g_{b}\right)
\end{array}
$$


第 1 項が個体概念間の代入により生成される節，第 2 項 がみなし代入による節である.第1 項における $\operatorname{sort}\left(\sigma_{p}(z)\right)$ や $\operatorname{sort}(z)$ および第 2 項における $g_{b}$ に代入 $\sigma_{p}$ を作用さ せているのは, 弚れらに含まれる変数が兴の代入に関与 する場合があるからである .

みなし代入は厳密には代入ではなく光の部分の概念間 だけの置換えである．したがって，SLp 節の生成だけに 関与し推論規則の他の部分に影響しない $\left(\sigma_{p}\right.$ に含まれる ものではない) .

また， 2.3 節で定義したようにソート概念は再帰構造 となるため, 光れに含まれる変数は多層にネストした形 となり得る (3.2 節の EOS での例を参照) . したがって， この変数に関する代入操作が問題となるが，これについ てはネスト構造の変数のうち, 代入可能な最も外側の変 数に対して行う（关の内側の層の変数の代入は後の推論 規則適用時に行う）. 以下にSLp 節の生成例を示す.

(1) $S_{1}=$ 都会の専門家 $(x$ :賢者 $)$

$S_{2}=[$ 東京: $\mathrm{T}]$ の医者 $($ 太郎: $\top \mathrm{T})$

$\cdots \mathrm{SLp}=$ 都会 (東京: $\mathrm{T}$ )

(2) $S_{1}=$ [政治家 $]\{$ 支持する $(x$ :青年 $)\}$ から $[x$ :青年 $]$ への連絡

$S_{2}=\left[c_{1}:\right.$ 社長 $]$ から $\left[c_{2}:\right.$ 学生 $]$ への手紙

$\cdots \mathrm{SLp}=$ 青年 $\left(c_{2}\right.$ :学生 $)$

$\wedge$ [政治家 $]\left\{\right.$ 支持する $\left(c_{2}:\right.$ 学生 $\left.)\right\}\left(c_{1}\right.$ :社長 $)$

(3) $S_{1}=[x:[$ 企業 $]\{$ 営む $(y$ :富豪 $)\}]$ の従業員 $(z$ :青年 $)$

$S_{2}=\left[c_{1}:[\right.$ 会社 $]\left\{\right.$ 営む $\left(c_{2}\right.$ :青年 $\left.)\right\}$ の社員 (太郎: $丁$ )

$\cdots \mathrm{SLp}=[$ 企業 $]\{$ 営む $(y$ :富豪 $)\}\left(c_{1}:\right.$ :会社 $]\{$ 営 む $\left(c_{2}:\right.$ :青年 $\left.\left.)\right\}\right)$

(1)は単純なみなし代入の例，(2)は $g_{b}$ に代入 $\sigma_{p}$ を作用 させる例である . (3)は変数がネストしている場合の例で あり，代入 $\sigma_{p}$ は $\left\{x=c_{1}\right\}$ のみで $y$ への $c_{2}$ の代入は行 わない．この代入は， 3.2 節の最後に述べた場合と同樣 にこの SLp 節が直接満たされない場合に ER を適用する 段階で行う.

\section{5. 推論処理の具体例}

以下のような自然言語文による問題を想定した，推論 処理の流れの例を図 3 に示す．

・若者が先進国の資産家が営む企業で働いているな ら，弚の若者は裕福である。

・太郎は花子が営む会社で働いている.

・花子は日本の財閥である.

・ 日本は先進国である.

·太郎は青年である.

・太郎は裕福ですか?

これらの文はWPL では同図のような表現となる .

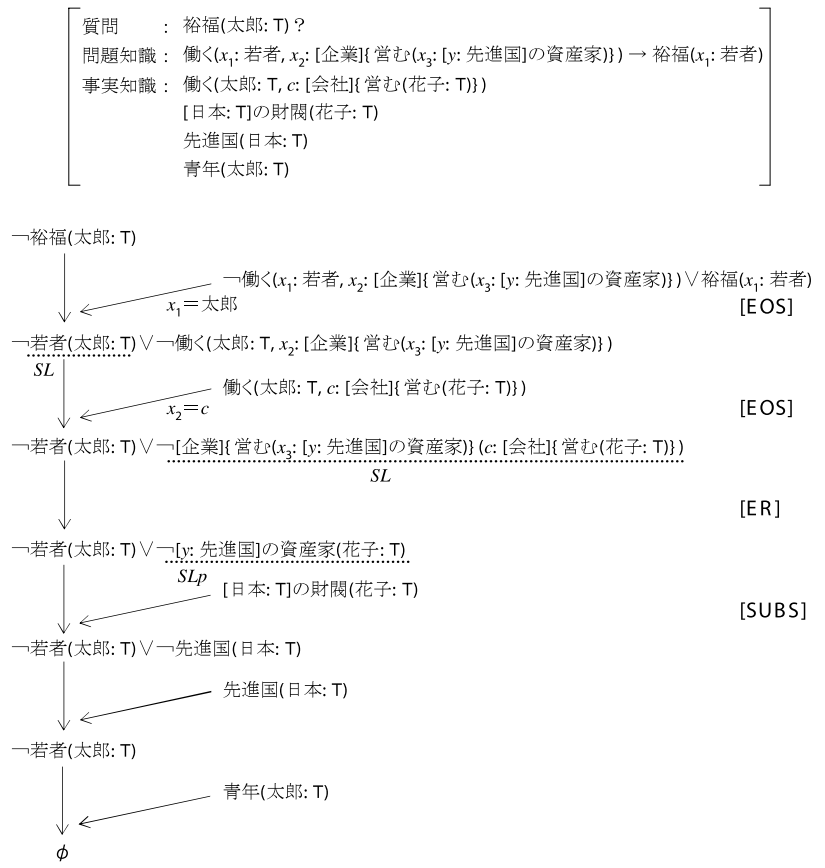

図 3 推論処理の流れ

推論は,同図から分かるように拡張した EOS,ER,SUBS を順次適用し，適宜代入とみなし代入を行い，SL 節や SLp 節を作成しつつ進められる．なお，提案手法は基本 的に日本語以外にも適用可能である [Kitano 06] .

\section{6. 考 察}

(1) 従来の順序ソート論理に対する優位性

従来の順序ソート論理における関数と本論文で提案し た構造を持ったソートとの差異について考察し，本手法 の推論処理上の優位性について述べる .

関数は個体あるいはいくつかの個体を他の一つの個体 に写像する機能であり，関数自体は光の写像された個体 を表す.これに対し，ここで提案した構造を持ったソー 卜は, 主概念のソートか㳔象とする個体の領域を修飾概 念により限定するものであり，弚れ自体はあくまで個体 の領域を表す．すなわち，関数とは本質的に異なり，推 論処理上以下のような優位性を持つ .

推論において関数を扱う場合，個体間の写像関係をあ らかじめ求めておくか, 必要になった時点 (単一化時) で 兴の関係を求めるかのいずれかとなろう . 前者の場合に は写像関係を示すテーブルを，後者の場合には関数毎に その值を計算するルーチンを用意することとなる．これ は，構成の複雑さだけでなく，対話システム等実時間の 応用を想定した場合には非現実的と言えよう（名詞句を 含む文が入力される毎にこれらを作成する必要があるの で). これに対し提案手法では，4章のサブソート関係の 判定ルーチンだけ用意すればよい(なお， 2.3 節でも述べ たが提案手法では基本的に関数は不要).

さらに推論能力についても以下のような優位性を持つ. 
例えば提案手法では， $L_{1}^{\prime} と L_{2}$ が光れ午れ，“裕福 $(x:[\mathrm{z}:$ 会社] の経営者)”, “裕福 ( $c$ : [ $c_{1}$ :企業] の経営者)” のとき に EOS を適用すると，SL 節として“[ $[z$ :会社] の経営者 $\left(c:\left[c_{1}\right.\right.$ :企業 $]$ の経営者 $) ”$ が作られ，この否定か導出節とな る.従って, もし “[ $c_{2}$ :会社 $]$ の経営者 $\left(c:\right.$ : $c_{1}$ :企業 $]$ の経営 者)” という事実知識 ( $c$ が $c_{1}$ という企業の経営者であり， かつ， $c_{2}$ という会社の経営者でもある)があれば，SUBS により空節が導かれることになる．この事実知識がなく ても，上記の SL 節に ER を適用し，SLp 節として “会 社 ( $c_{1}$ :企業)”が作られ，これが満たされればやはり空節 が導かれる (この適用順については 3.2 節の最後の記述 を参照) .

一方，これら $L_{1}^{\prime} ， L_{2}$ 中の名詞句を関数を用いて表す と, 光れ午れ“裕福 $\left(f(z:\right.$ 会社):経営者 $)$ ”, “裕福 $\left(f\left(c_{1}\right.\right.$ : 企業):経営者)”となる $(f$ は “括弧内の個体の経営者”を 意味する関数) . これらを従来の順序ソート論理 (Beierle らの EOS) で処理すると，SL 節として “会社 ( $c_{1}$ :企業)” が作られ，この否定が導出節となるだけである.すなわ ち, これが満たされない限り $\left(c_{1}\right.$ が会社でない限り), 空 節は導けないことになる $\left(c_{1}\right.$ という企業の経営者が $c_{2}$ と いう会社の経営者であったとしても) .すなわち，提案手 法では空節が導けるのに対し，従来のソート論理では導 けない場合があることになる．

さらに, 当然のことだが, 名詞句を関数で表わす場合 乥れが全く同一でなければ単一化の対象とならないが， 提案手法では名詞句の構造さえ同一なら关の対象となり， 4 章のサブソート関係の判定で推論処理可能である . 例 えば，複文を表すときの節述語 $L_{p}$ の述語部が異なる場 合でも，提案手法では产の階層関係を判定でき単一化の 対象となり得る。一方, 関数を用いれば必然的に異なる 関数となってしまい, 単一化の対象にならず推論処理で きない .

\section{(2) 推論の健全性と完全性}

ここで提案した推論法は, 基本的には Beierle らの手法 [Beierle 92] の拡張であり，定義 3 で規定した SLp 節が 正しく生成できれば产の健全性と完全性は保たれる（概略 的な健全性の証明のみ付録に示す)．しかし，4章て提案 したサブソート関係の判定法さらには光れに基づくSLp 節の生成法は, 多義性や係り受けの曖昧性を考慮しない 近似的なものである。したがって，これらを考慮した場合 には健全性と完全性は保たれるとは言えなくなる，例え ば, “会社のパソコン” と“企業のパソコン”では“の” の 意味が同じなら前者は後者のサブソートとなるが，実際 的な問題においては乥れらの同一性は保証されない．す なわち，すべてのソート概念のサブソート関係が一義に 定まる場合 (予め定義されている等) を除き，本推論法は 概略的な推論法とならざるを得ない．これは，3.1 節で も述べたように自然言語文の意味を扱う推論においては 本質的に避けられない問題である .

なお，推論規則自体の健全性・完全性に関する厳密な
証明については別途報告する予定である．

(3) ソート階層の解䣋

ソート概念間のサブソート関係は単語間の光れに基づ いて判定することになり，実用上は既存のシソーラス情 報 [EDR 96, 池原 02] の利用か想定される.しかし , シ ソーラスは基本的に固定的な is-a や a-kind-of の関係で あり，順序ソート論理に適用する場合，我々の感覚とズ レが生じることがある，例えば，“太郎は機械を直せま す . 太郎は時計を直せますか? ” では，順序ソート論理 で考えると時計 $\subseteq$ 機械 とすれば答えは “yes”となる． 時計は機械の一種なので一般的に考えれば正しいが, 直 感的には, 普通の機械が直せても構造が精巧て緻密な時 計は直せないと考えるかもしれない(むしろ常識的には “no”あるいは “分かりません”が妥当) .すなわち, サブ ソート関係は視点に応じて動的に変化させるべきといえ る.例えば，この例では “直す”という視点に立てば時 計 $\subseteq$ 機械とは言えなくなる．

また， 2.4 節て例示した “太郎は医者になるために勉強 する”という文があり，“太郎は専門家になるために勉強 するのですか?”という問いがあったとする .この場合， 順序ソート論理で考えると医者 $\subseteq$ 専門家なので答えは “yes”となる . “yes”でよいとも言えるが，上記の例と同 樣に“目的”という視点に立てば答えは “no”とも言える．

すなわち，このような視点を考慮した動的な判定は今 後の重要な課題と言える.

(4) 推論の高速化

SL 節やSLp 節を生成して推論を進める手法は, 本質的 に解が得られる可能性は高まるが, 探索空間の拡大によ りソート論理の利点の一つである高速性を損なうことに なる、したがって，これらの過剩な生成は押さえるべきで あり，兴のためにはソート間の排他性 [兼岩 02] のチェッ クが必要と言える．また, 述語のソート階層 [Kaneiwa 04] を考慮した階層的な推論法 [Tenenberg 89] との結合 も有効と考えられる .

(5) 構造を持ったソートに関する研究

これについてはいくつかの研究例があるが，これらは 主にソートを論理積や論理和等により結合した構造を対 象としていた [Pletat 89, Nebel 89] ．ソートにより規定 される個体を集合論的に扱え，弚の範囲において暧昧性 が介入しないからである.しかし, 自然言語文から論理 式への自動変換をも含めて考えたとき, 文中からこのよ うな構造を抽出し前述のような結合に変換するのは現時 点では極めて困難と言える .

\section{7. ま と め}

名詞句のような構造を持ったソートを許容する順序ソー 卜論理ベースの知識表現法 WPL と乥の推論法について 提案した . 従来の順序ソート論理においては, 知識表現 時および推論時にこのような構造を持ったソートもひと 
つの概念 (言語内でソート階層として定義される) として 扱っていた .これに対し提案手法は, 知識表現時にはひ とつの概念として扱うが，推論時には光の内部構造まで に立ち入って導出処理を行える推論法および光れを可能 とする知識表現法と言える .

WPL は, 知識構成要素を日常語とする自然言語文か らの自動変換を意識した知識表現法であり，構造を持っ たソートを用い単文だけでなく複文もひとつの述語式で 見通し良く表現される。これにより，基本的に関数の利 用も不要となる.また，これに対する推論法では, ソート 内の変数に対する代入操作および一般概念に対するみな し代入を行い, 光れが適切になる条件を導出節に付加し 推論を進めるように，Beierle らの推論規則を拡張した .

また , この推論法は, サブソート関係を判定 (構造を 持ったソート間のサブソート関係は光れを構成する基本 概念間のソート階層を基に判定) しながら推論を進める もので, この関係か溉定義な従来の推論法とは基本的に 異なる枠組みと言える，光の健全性と完全性はこの判定 の正確さに依存することとなるが, 自然言語の持つ曖昧 性を考慮したときこれを厳密に追及することはあまり現 実的ではないと考える．すなわち，自然言語を対象とし た推論は概略的なものにならざるを得ないと言え，こう いった視点も今後重要と考える.

\section{$\diamond$ 参 考 文 献 $\diamond$}

[Antoniou 07] Antoniou, G. and Bikakis, A.:DR-Prolog:A System for Defeasible Reasoning with Rules and Ontologies on the Semantic Web, IEEE Trans. Knowledge and Data Engineering, Vol.19, No.2, pp.233-245 (2007)

[Beierle 92] Beierle, C., Hedtstuck, U., Pletat, U., Schmitt, P. H., Siekmann, J.:An order-sorted logic for knowledge representation systems, Artificial Intelligence, Vol.55, pp.149$191(1992)$

[Brachman 84] Brachman, R. J. and Levesque, H. J.:The tractability of subsumption in flame-based description language, Proc. National Conf. on Artificial Intelligence, pp.3437 (1984)

[Cohn 87] Cohn, A. G.:A more expressive formulation of many sorted logic, Journal of Automated Reasoning, Vol.3, pp.113-200 (1987)

[EDR 96] 日本電子化辞書研究所:EDR 電子化辞書 (1996)

[Fuchs 06] Fuchs, N. E., Hoefler, S., Kaljurand, K., Kuhn, T., Schneider, G., Schwertel, U.:Discourse Representation Structures for ACE 5, Technical Report ifi-2006.10, Department of Informatics, University of Zurich pp.1-51 http://www.ifi.unizh.ch/attempto (2006)

[池原 02] 池原, 宮崎, 白井, 横尾, 中岩, 小倉, 大山, 林:日本語語 彙大系, 岩波書店 (1997)

[石川 04] 石川勉, 佐々木智彦, 佐藤雅彦:言葉をべースとする拡張 型述語論理形式の知識表現法, 人工知能学会ことば工学研究会 資料 SIG-LSE-A303 pp.25-32 (2004)

[石川 07] 石川勉:自然言語文からの論理式生成と推論, 人工知能 学会誌, Vol.22, No.5, pp.613-620 (2007)

[石塚 06] 石塚満:自然言語テキストの共通的概念記述, 人工知能 学会誌, Vol.21, No.6, pp.691-698 (2006)

[兼岩 00] 兼岩憲, 東条敏:ソートと述語の二つの階層をもつ論理 のホーン節計算の完全性, 電子情報通信学会論文誌 Vol.J83-D-I, No.12, pp.1239-1248 (2000)

[兼岩 02] 兼岩憲, 東条敏:否定的意味が内在するソートを含んだ
ソート階層の論理, 情報処理学会論文誌, Vol.43, No.5, pp.1505$1517(2002)$

[兼岩 03] 兼岩憲, 佐藤健:DL:Description Logic, 人工知能学会 誌, Vol.18, No.1, pp.73-82 (2003)

[Kaneiwa 04] Kaneiwa, K.:Order-sorted logic programming with predicate hierarchy, Artificial Intelligence 158 pp.155$188(2004)$

[兼岩 05] 兼岩憲, 溝口理一郎:形式オントロジーと順序ソート論理 の拡張, 人工知能学会論文誌,Vol.20, No.6, pp.387-395 (2005)

[Kitano 06] Kitano, M., Nishita, S. and Ishikawa, T.:Inference Scheme for Order-Sorted Logic Using Noun Phrases with Variables as Sorts, Proc. 5th Mexican Int. Conf. on Artificial Intelligence, Springer-Verlag LNAI 4293, pp.49-58 (2006)

[黑橋 07] 黑橋禎夫:言語コンピューティング, 人工知能学会誌, Vol.22, No.5, pp.711-720 (2007)

[益岡 00] 益岡隆志:複文, くろしお出版 (2000)

[松本 04] 松本裕治, 高岡一馬, 浅原正幸, 工藤拓: 茶筅と南瓜によ る日本語解析 - 構文情報を用いた文の役割分類 - , 人工知能学 会誌, Vol.19, No.3, pp.334-339 (2004)

[Montague 73] Montague, R.:The Proper Treatment of Quantification in Ordinary English, in J. Hintikka, J. Moravcsik and P. Suppes (eds.), Approaches to Natural Language, Reidel, Dordrecht, pp.221-242 (1973)

[Nebel 89] Nebel, B. and Smolka, G.:Representation and Reasoning with Attributive Descriptions, Springer-Verlag LNAI Vol.418, pp.112-139 (1989)

[Pletat 89] Pletat, U. and von Luck, K.:Knowledge Representation in LILOG, Springer-Verlag LNAI Vol.418, pp.140164 (1989)

[佐々木 04] 佐々木智彦, 石川勉:連結定数で結合された素式群に よる複文の述語知識表現法と关れへの変換法, FIT2004, E-017 (2004)

[白井 85] 白井賢一郎:形式意味論入門 - 言語·論理·認知の世界 産業图書 (1985)

[竹内 02] 竹内孔一, 内山清子, 吉岡真治, 影浦峡, 小山照夫:語彙 概念構造を利用した複合名詞内の係り関係の解析, 情報処理学 会論文誌,vol.43, No.5, pp.1446-1456, (2002)

[Tenenberg 89] Tenenberg, D. J.:Abstracting first-oder theories, in Change of Representation and Inductive Bias, pp.6779, Kluwer Academic (1989)

[UNL] Universal Networking Digital Language (UNDL), http://www.undl.org/

[Walther 88] Walther, C.:Many-sorted unification, J. Association for Computing Machinery, Vol.35, No.1, pp.1-17 (1988)

\section{〔担当委員：兼 岩 憲〕}

2008 年 2 月 19 日 受理

$$
\diamond \text { 付 録 } \diamond
$$

\section{A. 健全性の証明}

最も複雑な SUBS(本文中の式 (9) と (10)) について証明する . まず以下を証明する .

$$
\frac{\neg S_{1}\left(t_{1}\right) \vee A, S_{2}\left(t_{2}\right) \vee B}{\left[\sigma_{p}^{\prime}\left[\neg S_{1}\left(t_{1}\right) \vee A\right], \sigma_{p}^{\prime}\left[S_{2}\left(t_{2}\right) \vee B\right]\right] \vee \neg S L p}
$$

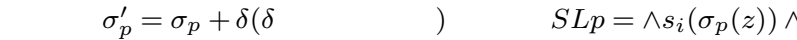
$s_{i}^{\prime}(t)$ とする (第 1 項は $\sigma_{p}$ による，また第 2 項は $\delta$ による SLp 節 (ソート述語の連言))

式 (A.1) は，

$\forall x_{1}: s_{1} \cdots \forall x_{m}: s_{m} \forall z_{m+1}: s_{m+1} \cdots \forall z_{n}: s_{n}\left[\neg S_{1}\left(t_{1}\right) \vee A\right]$

$\forall x_{1}: s_{1} \cdots \forall x_{m}: s_{m} \forall z_{m+1}: s_{m+1} \cdots \forall z_{n}: s_{n}\left[S_{2}\left(t_{2}\right) \vee B\right]$ を充足するモデルを $G$ としたとき，この $G$ が以下を充足すれば成 り立つ。 
$\forall x_{1}: s_{1} \cdots \forall x_{m}: s_{m}\left[\left[\sigma_{p}^{\prime}\left[\neg S_{1}\left(t_{1}\right) \vee A\right], \sigma_{p}^{\prime}\left[S_{2}\left(t_{2}\right) \vee B\right]\right] \vee \neg S L p\right]$ ここで, $x_{i}$ は項の変数であり， $z_{i}$ は $S_{1}, S_{2}$ 中の変数である .

モデル $G$ において, $\operatorname{dom}\left(\sigma_{p}\right)$ 内のある変数 $z_{i}$ について

$\models_{G} \neg s_{i}\left(\sigma_{p}(z)\right)$

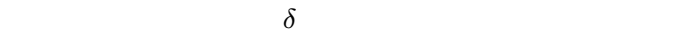

$\models_{G} \neg s_{i}^{\prime}(t)$

とすると，これらは $S L p$ に含まれるので当然，以下が言える .

$\models_{G} \neg S L p$

一方, すべての変数 $z_{i}$ について

$\models_{G} s_{i}\left(\sigma_{p}(z)\right)$

および，みなし代入 $\delta$ におけるすべての個体概念について

$\models_{G} \quad s_{i}^{\prime}(t)$

とすると, これらの代入操作をもとの $\neg S_{1}\left(t_{1}\right) \vee A$ と $S_{2}\left(t_{2}\right) \vee B$

に対して行った結果も充足される.すなわち，

$\models_{G} \quad \sigma_{p}^{\prime}\left[\neg S_{1}\left(t_{1}\right) \vee A, S_{2}\left(t_{2}\right) \vee B\right]$.

したがって，モデル $G$ は，

$\forall x_{1}: s_{1} \cdots \forall x_{m}: s_{m}\left[\left[\sigma_{p}^{\prime}\left[\neg S_{1}\left(t_{1}\right) \vee A\right], \sigma_{p}^{\prime}\left[S_{2}\left(t_{2}\right) \vee B\right]\right] \vee \neg S L p\right]$ を充足し式 (A.1) が成り立つ.

次に上式は，みなし代入 $\delta$ が $S_{1} ， S_{2}$ だけを対象とするので，

$\left[\sigma_{p}^{\prime}\left[\neg S_{1}\left(t_{1}\right) \vee A\right], \sigma_{p}^{\prime}\left[S_{2}\left(t_{2}\right) \vee B\right]\right] \vee \neg S L p$

$=\left[\neg \sigma_{p}^{\prime}\left[S_{1}\right]\left(\sigma_{p}\left[t_{1}\right]\right) \vee \sigma_{p}[A], \sigma_{p}^{\prime}\left[S_{2}\right]\left(\sigma_{p}\left[t_{2}\right]\right) \vee \sigma_{p}[B]\right] \vee \neg S L p$

$=\left[\neg S_{1}^{\prime}\left(t_{1}^{\prime}\right) \vee A^{\prime}, S_{2}^{\prime}\left(t_{2}^{\prime}\right) \vee B^{\prime}\right]$

と变形できる.ここで, $S_{1}^{\prime}=\sigma_{p}^{\prime}\left[S_{1}\right], t_{1}^{\prime}=\sigma_{p}\left[t_{1}\right], A^{\prime}=\sigma_{p}[A] \vee$ $\neg S L p, S_{2}^{\prime}=\sigma_{p}^{\prime}\left[S_{2}\right], t_{2}^{\prime}=\sigma_{p}\left[t_{2}\right], B^{\prime}=\sigma_{p}[B] \vee \neg S L p$ である.

$\mathrm{SLp}$ 節は定義 3 から $S_{2} \subseteq S_{1}$ を満たすための条件であるから， $\sigma_{p}^{\prime}$ を適用した $S_{1}^{\prime}, S_{2}^{\prime}$ 間では $S_{2}^{\prime} \subseteq S_{1}^{\prime}$ が成り立ち, 上式に対し Beierle 等の SUBS(式 (4)) を適用できる.この結果， $\sigma\left(A^{\prime} \vee B^{\prime}\right) \vee \neg S L(\sigma)$ か檤かれる $\cdot A^{\prime}, B^{\prime}$ をもとに戻すと

$\sigma\left(A^{\prime} \vee B^{\prime}\right) \vee \neg S L(\sigma)$

$=\sigma\left(\left(\sigma_{p}[A] \vee \neg S L p\right) \vee\left(\sigma_{p}[B] \vee \neg S L p\right)\right) \vee \neg S L(\sigma)$.

変数 $x$ は $S_{1}, S_{2}$ に含まれず $\mathrm{SLp}$ 節にも含まれないので, $\sigma(S L p)=$ $S L p$ であり,

$=\sigma \sigma_{p}(A \vee B) \vee \neg S L p \vee \neg S L(\sigma)$.

これにより式 (9) は証明された .

また , 上式における $S L(\sigma)$ は, $\sigma$ が項の変数に対する代入であ り，兴のソート部には代入 $\sigma_{p}$ が作用されているので, 式 (2) 中の $\operatorname{sort}(\sigma(x))$ および $\operatorname{sort}(x)$ に $\sigma_{p}$ を作用させる必要がある .これに より式 (2) は式 (10) と同一になり, 式 (10) が証明された .

なお， $\operatorname{EOS}($ 式 (7),(8))，ER(式 (11)) の健全性も同樣に証明で きる

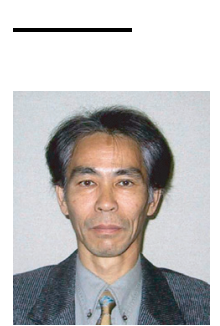

石川勉(正会員)

1970 年電気通信大学電気通信学部応用電子工学科卒業。 同年現 NTT 入社. 1995 年拓殖大学工学部情報工学科教 授. 柔らかな情報処理のための人工知能の研究に従事. I 学博士. 電子情報通信学会, 情報処理学会, IEEE 各会員。 